\title{
Growth patterns of the lanternfish Ceratoscopelus maderensis in the western Mediterranean Sea
}

\author{
Enric Real ${ }^{1,2}$, Ainhoa Bernal ${ }^{1}$, Beatriz Morales-Nin ${ }^{3}$, Balbina Molí ${ }^{1}$, Itziar Alvarez ${ }^{3}$, \\ M. Pilar Olivar ${ }^{1}$ \\ ${ }^{1}$ Institut de Ciències del Mar (ICM-CSIC), Passeig Marítim de la Barceloneta 37-49, 08003 Barcelona, Spain. \\ (ER) E-mail: enrique.real @ieo.es. ORCID-iD: https://orcid.org/0000-0002-6190-6303 \\ (AB) (Corresponding author) E-mail: bernal@icm.csic.es. ORCID-iD: https://orcid.org/0000-0001-8321-1919 \\ (BM) E-mail: balbina@icm.csic.es. ORCID-iD: https://orcid.org/0000-0002-8545-4567 \\ (MPO) E-mail: polivar@icm.csic.es. ORCID-iD: https://orcid.org/0000-0002-8887-9181 \\ ${ }_{2}^{2}$ Instituto Español de Oceanografía, Centro Oceanográfico de Baleares, Marine Reserves Group (RESMARIEO), \\ Moll de Ponent s/n, 07015 Palma de Mallorca, Spain. \\ ${ }^{3}$ Institut Mediterrani d'Estudis Avançats IMEDEA (CSIC-UIB), Miquel Marquès 21, 07190 Esporles, Illes Balears, Spain. \\ (BM-N) E-mail: beatriz@ imedea.uib-csic.es. ORCID-iD: https://orcid.org/0000-0002-7264-0918 \\ (IA) E-mail: itziar@imedea.uib-csic.es. ORCID-iD: https://orcid.org/0000-0003-4128-9149
}

\begin{abstract}
Summary: The age and growth patterns of the mesopelagic fish Ceratoscopelus maderensis (family Myctophidae) of the western Mediterranean Sea were described throughout its entire life cycle (from larvae to adult stages) using the sagittae otoliths of 59 individuals collected in December 2009. Three characteristic zones were identified along the cross-section of the sagittae (larval, metamorphic and juvenile-adult zones). Assuming growth rings as daily increments, the age of the analysed individuals (from 3.5 to $64 \mathrm{~mm}$ standard length [SL]) would range from 7 to 332 days. The relationship between the number of increments and the fish SL was fitted to a von Bertalanffy growth model $\left(S L=70.5899 \times\left(1-\exp ^{(-0.0501(t+2.6705))}\right)\right.$. The growth pattern of $C$. maderensis in the western Mediterranean Sea was similar to that reported for this species in the northeast Atlantic Ocean. Though from a body size of $40-45 \mathrm{~mm}$ SL, growth rates declined more slowly in individuals from the western Mediterranean Sea, growth differences between these individuals and those from the northeast Atlantic Ocean were not statistically significant. This study provides new insights into the age and growth patterns of one of the most abundant mesopelagic fish species in the Mediterranean Sea that have clear implications for the study and management of marine ecosystems.
\end{abstract}

Keywords: daily growth, larval growth, mesopelagic fish, Myctophidae, otolith microstructure.

Patrones de crecimiento del pez linterna Ceratoscopelus maderensis en el Mediterráneo occidental

Resumen: En el presente trabajo se describen la edad y los patrones de crecimiento desde la fase larvaria hasta la fase adulta del pez mesopelágico Ceratoscopelus maderensis (familia Myctophidae) del Mediterráneo occidental. Para ello, se analizó el otolito sagitta de 59 individuos capturados en diciembre de 2009. Se identificaron tres zonas en la sagitta, cada una de las cuales se corresponde con una fase del desarrollo ontogenético del pez: larvaria, metamórfica y juvenil-adulta. Asumiendo que los anillos de crecimiento son diarios, la edad de los individuos analizados (de 3.5 a $64 \mathrm{~mm}$ de longitud estándar [SL]) oscilaría entre 7 y 332 días. La relación entre el número de incrementos y la SL de los peces se ajustó al modelo de crecimiento de von Bertalanffy $\left(S L=70.5899 \times\left(1-\exp ^{(-0.0501(t+2.6705))}\right)\right.$. El patrón de crecimiento de C. maderensis en el Mediterráneo occidental fue similar al previamente descrito para esta especie en el Noreste del Océano Atlántico. A pesar de que, a partir de 40-45 mm SL, las tasas de crecimiento disminuyeron más lentamente en los individuos del Mediterráneo occidental, las diferencias de crecimiento entre estos individuos y los del Noreste del Océano Atlántico no fueron estadísticamente significativas. Los resultados de este estudio aportan nuevos conocimientos sobre la edad y el crecimiento de una de las especies más abundantes del Mar Mediterráneo, lo cual tiene claras implicaciones de cara al estudio y la gestión de los ecosistemas marinos.

Palabras clave: crecimiento larvario, crecimiento diario, microestructura del otolito, Myctophidae, peces mesopelágicos.

Citation/Como citar este artículo: Real E., Bernal A., Morales-Nin B., Molí B., Alvarez I., Olivar M.P. 2021. Growth patterns of the lanternfish Ceratoscopelus maderensis in the western Mediterranean Sea. Sci. Mar. 85(2): 71-80. https:// doi.org/10.3989/scimar.05106.007

Editor: V.M. Tuset.

Received: July 17, 2020. Accepted: February 1, 2021. Published: May 28, 2021.

Copyright: ( $) 2021$ CSIC. This is an open-access article distributed under the terms of the Creative Commons Attribution 4.0 International (CC BY 4.0) License. 


\section{INTRODUCTION}

Ceratoscopelus maderensis (Lowe, 1839) is a lanternfish species (Myctophidae) that is generally found in mesopelagic waters at depths ranging from 200 to $1000 \mathrm{~m}$ between $50^{\circ} \mathrm{N}$ and $30^{\circ} \mathrm{N}$ in the North Atlantic Ocean (Hulley 1984) and throughout the Mediterranean Sea (Jonsson 1992, Cavallaro et al. 2019). Its larval stages inhabit the epipelagic layer, mostly concentrated in the first $50 \mathrm{~m}$ of the water column. When the transformation (metamorphic) stage is reached, individuals begin to move to the mesopelagic zone (Kendall et al. 1984, Richards 2005, Sassa et al. 2007). From this period onward, like most myctophid species, C. maderensis acquires a nictoepipelagic behaviour that implies diel vertical migrations between $c a .1000$ $m$ depth and the surface (Hulley 1984, Mytilineou et al. 2005, Olivar et al. 2012).

Ceratoscopelus maderensis is one of the most abundant myctophid species in the northeastern Atlantic Ocean and the Mediterranean Sea (Goodyear et al. 1972, Hulley 1981, Olivar et al. 2012). As such, this species occupies a key position in the food-web structure of the mesopelagic community feeding on zooplankton (Bernal et al. 2015), which highlights its integral role in the functioning of oceanic ecosystems as an intermediate link between primary consumers and top predators (Gjøsaeter and Kawaguchi 1980, Sassa and Takahashi 2018, Anderson et al. 2019). Despite its important ecological role, the populations of $C$. maderensis remain one of the least well-studied components of marine ecosystems at both a regional and a global scale (St. John et al. 2016). Several studies have reported growth patterns in myctophid species (e.g. Gartner 1991a, Linkowski et al. 1993, Sassa et al. 2015), but despite their wide geographical distribution, there is still a lack of information on their growth rates and lifespan.

Accurate age determinations provide basic life-history information and are imperative for describing population dynamics at the species level. Most age-determination studies on myctophids are based on the counting of daily growth increments (Brothers et al. 1976, Methot and Kramer 1981, Gjøsaeter 1987) or seasonal growth increments in sagittae otoliths (Sarmiento et al. 2018), length-based analysis (Ricker 1975 and references therein, Harvey et al. 2000) or a combination of these methods (Aguilar-Perera and Quijano-Puerto 2016, Saunders et al. 2020). Microincrements in the otoliths of myctophids appear to be equivalent to daily rings that have been validated in other myctophids directly by considering their formation over periods of 24 hours (Gartner 1991a, b, Moku et al. 2005) and indirectly by the back-calculation of birth dates from the age, date of capture and timing with their spawning season (Young et al. 1988). Therefore, most studies about the growth and age of myctophids have assumed a daily micro-increment deposition (Greely et al. 1999, Hayashi et al. 2001, Wang et al. 2018).

Linkowsky et al. (1993) investigated the growth patterns of adult individuals of $C$. maderensis from the northeast Atlantic Ocean. However, the age and growth patterns of this species during its larval stage remained unknown so far, and no studies have been conducted in either early stages or adults from the Mediterranean Sea. The Mediterranean Sea is characterized by the near-constant water temperature below the thermocline $\left(100 \mathrm{~m}\right.$ depth) at $c a .13^{\circ} \mathrm{C}$ (Olivar et al. 2012, Houpert et al. 2015) and its relative oligotrophy (Estrada 1985, Morel and Andre 1991). This contrasts with the colder and more productive waters of the northeastern Atlantic Ocean, where temperatures range between $8^{\circ} \mathrm{C}$ and $18^{\circ} \mathrm{C}$ from $500 \mathrm{~m}$ depth to the surface (Emery and Meincke 1986). This could lead to dissimilar growth patterns in C. maderensis between the two biomes. Hulley (1984) showed that, in general, the maximum body size reached by mesopelagic fish species in the Atlantic Ocean was larger than that in the western Mediterranean Sea. However, several studies have also shown that higher temperature regimes can increase both otolith (Rountrey et al. 2014) and fish growth (Handeland et al. 2008, Silva et al. 2008). Further genetic studies on the populations of $C$. maderensis might confirm whether the species separated into two different stocks, one in the Atlantic Ocean and one in the Mediterranean Sea, with a biogeographical frontier in the Alboran Sea, as it has been demonstrated for many other fish species (Naciri et al. 1999).

The aims of the present study are i) to estimate the age and growth patterns of $C$. maderensis in the western Mediterranean Sea through the analysis of sagittae otoliths considering most of its entire lifecycle, and ii) to compare the growth patterns of this species in the western Mediterranean Sea with those reported by Linkowski et al. (1993) for this species with individuals from the northeastern Atlantic Ocean. We expect that the warmer temperatures in the Mediterranean Sea will make this species grow faster than in the northeastern Atlantic Ocean.

\section{METHODS}

\section{Fish sampling}

Sampling was performed on board the research vessel Sarmiento de Gamboa during a cruise carried out in December 2009 (late autumn). The study area was located to the northwest and southwest of Mallorca (Balearic Islands, western Mediterranean Sea, Fig. $1)$ at the shelf-break $(>200 \mathrm{~m}$ depth) and the median slope (700-900 m depth). A $280 \mathrm{~m}^{2}$ midwater trawl (10 $\mathrm{mm}$ mesh size in the cod-end) and a $3 \mathrm{~m}^{2}(3 \mathrm{~mm}$ mesh size) Isaacs- Kidd Midwater Trawl (IKMT) were employed to capture adult and juvenile fish. The depth where the fishing nets operated was controlled using a SCANMAR sensor. Fishing operations were performed both near the surface $(40-80 \mathrm{~m})$ and near the Deep Scattering Layer (DSL) at $400 \mathrm{~m}$ depth, where the echosounder recorded the highest acoustic signal at 18 and $38 \mathrm{kHz}$ (Olivar et al. 2012). The vessel speed was maintained at 4 knots for the large midwater trawl and 3 knots for the IKMT. After on-board fish identification using specific literature (Hulley 1981, 1984), the 


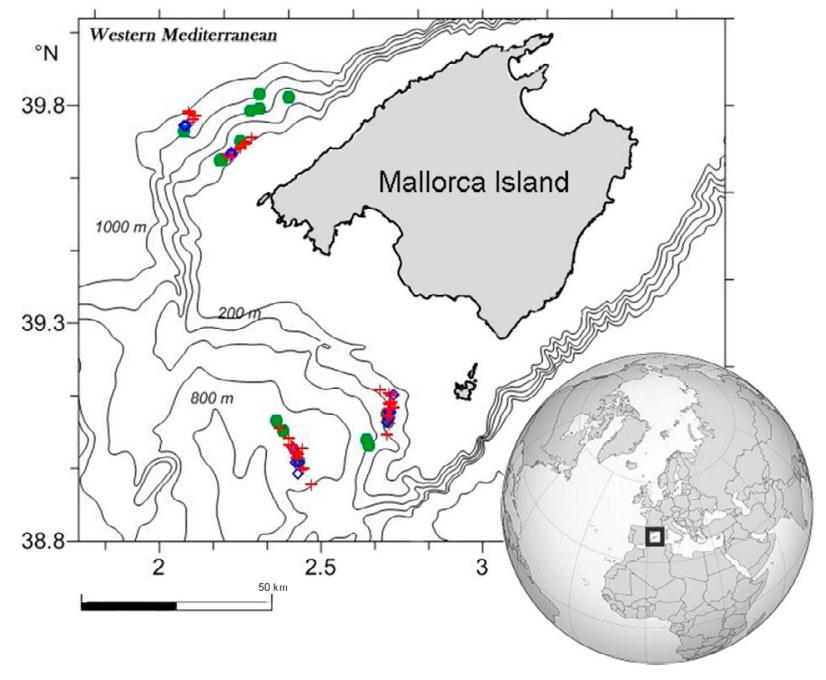

Fig. 1.-Study area where samples were collected in the northwestern and southwestern basins of Mallorca Island (Mediterranean Sea, December 2009). Sampling stations are represented according to the type of device employed: blue rhombuses correspond to HydroBios MultiNet, red crosses to Isaacs-Kidd Midwater Trawl and Rectangular Midwater Trawl, and green circles to pelagic trawls; see the Methods section.

specimens were frozen and stored at $-20^{\circ} \mathrm{C}$ to prevent otolith damage. The water column temperature was obtained with the SBE 911plus CTD at each station.

The collection of fish larvae and transformation stages was carried out at the same stations with a $0.25 \mathrm{~m}^{2} \mathrm{Hy}-$ dro-Bios MultiNet with $0.3 \mathrm{~mm}$ mesh size. Oblique tows at five discrete depths from $200 \mathrm{~m}$ to the surface were performed during a 24 -h cycle ( 8 in daytime and 8 at night). Ichthyoplankton samples were preserved in 5\% buffered formalin and sorted once in the laboratory. The $\mathrm{pH}$ was maintained at $c a$. 8 to prevent otolith degradation.

Fish larvae were sorted and identified in the laboratory using relevant literature (Tåning 1918, Moser and Watson 2006). Larvae were ascribed to preflexion, flexion and postflexion stages (according to the urostyle bending), or transformation stages (according to photophore development) (Kendall et al. 1984), and were measured to $0.1 \mathrm{~mm}$ precision under a microscope employing an ocular micrometre.

\section{Otolith preparation}

The standard length (SL) was measured before otolith extraction for 208 individuals, of which 45 were larvae $(<16 \mathrm{~mm} \mathrm{SL}), 49$ were individuals at the transformation stage (17-20 $\mathrm{mm} \mathrm{SL})$, and the remaining 114 were juveniles and adults $(>20 \mathrm{~mm} \mathrm{SL})$. For each individual, the left and right sagittae otoliths were extracted from the ear cavity. In the larval and transformation stages, the otolith extraction was performed using a fine needle, with the help of polarized light of the microscope for a better location of the otoliths. After drying, a drop of Cristal Bond $590^{\mathrm{TM}}$ thermolabile resin was poured over the otolith for further preservation. In the juveniles and adults, we first made a cross-sectional incision at the back of the fish head, near the rear of the operculum. Then, the two sagittae were extracted with forceps according to Secor et al. (1991). After the extraction, both otoliths were cleaned with a $5 \%$ solution of $\mathrm{KOH}$ to remove the attached organic tissue and then rinsed with water. The mounting and polishing were performed according to the methods described by Morales-Nin (1992) and Stevenson and Campana (1992). An otolith of each fish was mounted on a slide to polish its sagittae section, fixing the inner face with thermolabile resin.

The otolith length was defined from maximum diameter in larvae and from rostrum to posterior margin according to Tuset et al. (2008). In the smallest larvae (5-7 mm SL), the transparency of the otoliths allowed us to count growth increments without need for polishing. Otoliths from the transformation, juvenile and adult stages were manually polished with grinding lapping papers $(0.1-3 \mu \mathrm{m})$. In otoliths from larger specimens, the polishing process was interspersed with micrographs of the increments located in the margin of the otolith (the narrowest ones) to ensure the identification and the count of these increments and prevent any loss in the case of over-polishing. To increase transparency in thicker otoliths, the polishing process was carried out on both sides, taking care not to affect the maximum diameter of the otolith. Finally, the otoliths were ultra-polished with an abrasive consisting of a MicroCloth PSA 10/ PK 8 disc previously impregnated with an abrasive solution with $0.05 \mu \mathrm{m}$ of alumina. Daily increments were counted from images obtained with a digital camera mounted on an optical microscope (Zeiss Axioskop 2 Plus) and with the Image-Pro Plus v.5.0 image analysis software (magnification: $100 \times, 400 \times, 630 \times$ and $1000 \times$ ). Double readings were performed in the postrostrum otolith section. If the first reading was not coincident with the second one, a third reading was performed to guarantee the correct interpretation of age.

To determine whether the increment width was outside the resolution threshold of the optical microscope, some otoliths from the transformation stage $(n=1)$, and juvenile and adult stages $(n=5)$ were also examined at high resolution. Polished otoliths were immersed in a $1 \% \mathrm{HCl}$ solution for between 60 and 300 seconds, rinsed with water and allowed to air dry for 24 hours. Finally, the otoliths were mounted, covered with gold-palladium and then observed using a scanning electron microscope (SEM).

\section{Growth estimation}

In the Mediterranean Sea, C. maderensis is not sexually mature until it reaches $\geq 40 \mathrm{~mm}$ SL (Hulley 1981 , 1984). Specimens collected in this study were not sexed, so we cannot confirm whether there are size differences between sexes in individuals of $C$. maderensis from the western Mediterranean Sea. Therefore, in this study, specimens of both sexes were considered together. Linkowski et al. (1993) observed that individuals of $C$. maderensis from the northeastern Atlantic Ocean showed no significant size differences between males and females. The relationship between the fish length 
and the otolith diameter was determined by linear regression to ensure that the growth of the otolith is proportional to the somatic growth of the species. As each increment is assumed to represent one-day growth, the relationship between the number of day-increments and SL was fitted by a von Bertalanffy growth curve based on Equation 1:

$$
L_{t}=L_{\infty}\left[1-\mathrm{e}^{-k(t-t)} 0\right]
$$

where $L_{t}$ is standard length in $\mathrm{mm}, L_{\infty}$ is the asymptotic size in mm, $k$ in days ${ }^{-1}$ is the Brody growth rate coefficient, which measures the rate at which the growth rate declines, and $t_{0}$ corresponds to the age at which $L$ is 0 (von Bertalanffy 1938).

The absolute growth rate $\left(g_{t}\right)$ is given by $g_{t}=k\left(L_{\infty}-L_{t}\right)$, and when $t=0(\mathrm{w})$, the absolute growth rate is $w=k \times L_{\infty}$. Parameters $k$ and $L_{\infty}$ were fitted and estimated using R software.

Finally, a second von Bertalanffy growth curve considering adult specimens only (i.e. SL $>19 \mathrm{~mm}$ ) was fitted in order to assess for growth differences between our specimens from the western Mediterranean Sea and from the northeastern Atlantic Ocean measured by Linkowski et al. (1993) (individuals with SL $<19 \mathrm{~mm}$ were not considered by these authors). The comparison of these two curves was performed without fixing parameters or fixing one, two or all three parameters using the fisheries stock-assessment method package (FSA; Ogle 2016) in R software. According to this method, when the best explanatory models are those in which most of the parameters have not been fixed, this indicates that there are differences between the curves. By contrast, when the best models are those in which most parameters have been fixed, this indicates similarities between the curves. The best models were selected using the Akaike information criterion (AIC, Burnham and Anderson 2002). Models with AIC differences $\leq 2$ were considered equivalent (see Burnham and Anderson 2002, 2004).

\section{RESULTS}

A total of 208 individuals of $C$. maderensis were selected to cover the entire size range of the species in the western Mediterranean Sea. However, only 59 individuals $(28 \%)$ could be successfully processed because of difficulties in the preparation process. This is mainly because the counting of increments in the otoliths of larger specimens was only possible after obtaining extremely thin and delicate sheets that broke easily during polishing or when using the hot melting resin for fixing. Despite these difficulties, the number of otoliths successfully processed was large enough to constitute a representative sample of the size range of $C$. maderensis in the western Mediterranean Sea.

Larval otoliths were round and very small (otolith diameter in larval individuals ranged between 19.96 and $218.51 \mu \mathrm{m}$ ) but turned into an oval shape as the fish grows (Fig. 2). The size-frequency distribution of juvenile and adult stages showed two modal size classes (20 and $50 \mathrm{~mm}$ respectively) (Fig. S1).

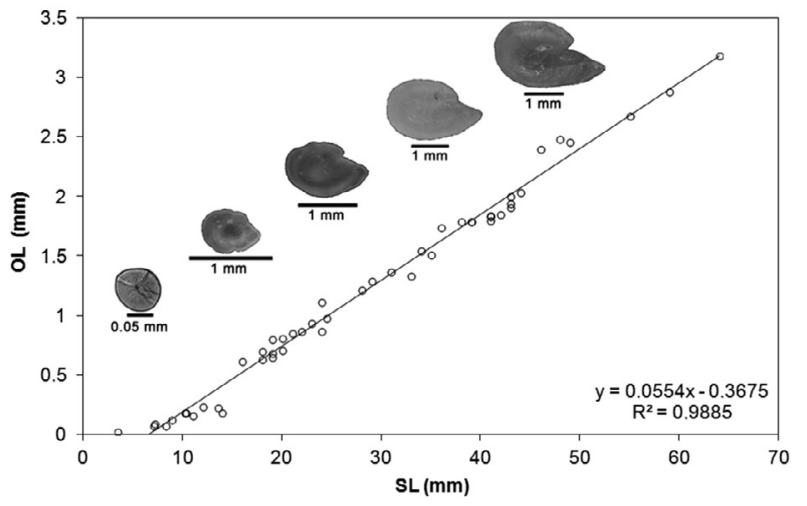

Fig. 2. - Linear regression between the maximum otolith diameter (OL) and fish length (SL) of Ceratoscopelus maderensis otoliths from the western Mediterranean Sea. The images show ontogenetic changes in the otolith shape with development.

\section{Microstructure of the otoliths}

The observation and the counting of otolith increments were feasible using both optical microscope and SEM. Three different zones were differenciated in adult specimens: larval (Fig. 3A, B), metamorphic (Fig. 3C, D), and juvenile-adult (Fig. 3E, F). Table 1 shows the SL ranges and the number of increments for each of these regions. The larval region was composed of a core (Fig. 3B) followed by a succession of an average of 27 increments $(n=9, \sigma=2.98)$. The mean radius between the centre of the core and the outer part of the first increment was $2.95 \mu \mathrm{m}(\mathrm{n}=3, \sigma=0.84)$, while the average radius of the larval zone was $125.34 \mu \mathrm{m}$ $(n=19, \sigma=30.46)$. Within the larval region, the increment thickness increased progressively following the exponential function:

$$
y=1.2196 e^{0.015 x}
$$

where $y$ corresponds to the thickness of the increments in $\mu \mathrm{m}$ and $x$ is the radius in $\mu \mathrm{m}\left(\mathrm{r}^{2}=0.91\right)$. The mean increment thickness in this region ranged from 1.4 to $4.2 \mu \mathrm{m}(\mathrm{n}=14, \sigma=0.88)$. The end of the larval region was well defined by a dark band of transition between the larval and metamorphic zones (Fig. 3A). This band was 5-10 $\mu \mathrm{m}$ wide and could also be detected using an optical microscope.

The metamorphic zone (Fig. 3C, D) extended from the external limit of the larval region (Fig. 3A) to the

Table 1. - Standard length (SL), number of increments for each developmental zone (larval, metamorphic and juvenile-adult) identified in the otoliths of $\mathrm{N}$ individuals of Ceratoscopelus maderensis from the western Mediterranean Sea.

\begin{tabular}{lccc}
\hline Development phase & SL $(\mathrm{mm})$ & Increments & $\mathrm{N}$ \\
\hline Larval & $\leq 14$ & $7-43$ & 12 \\
Metamorphic & $16-19$ & $42-69$ & 5 \\
Juvenile-adult & $19-64$ & $61-332$ & 42 \\
\hline
\end{tabular}




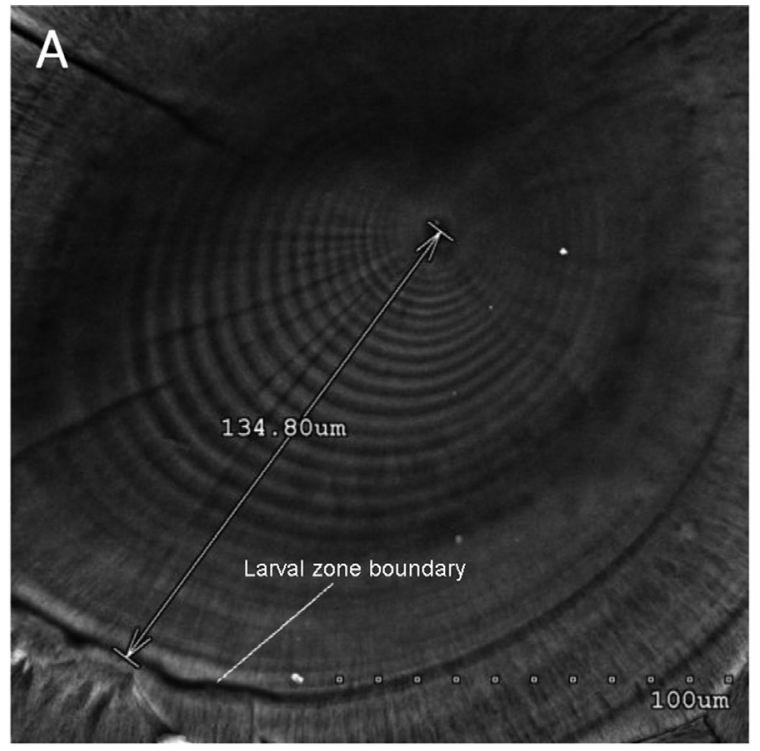

B

$$
\text { Core }-\cdots
$$

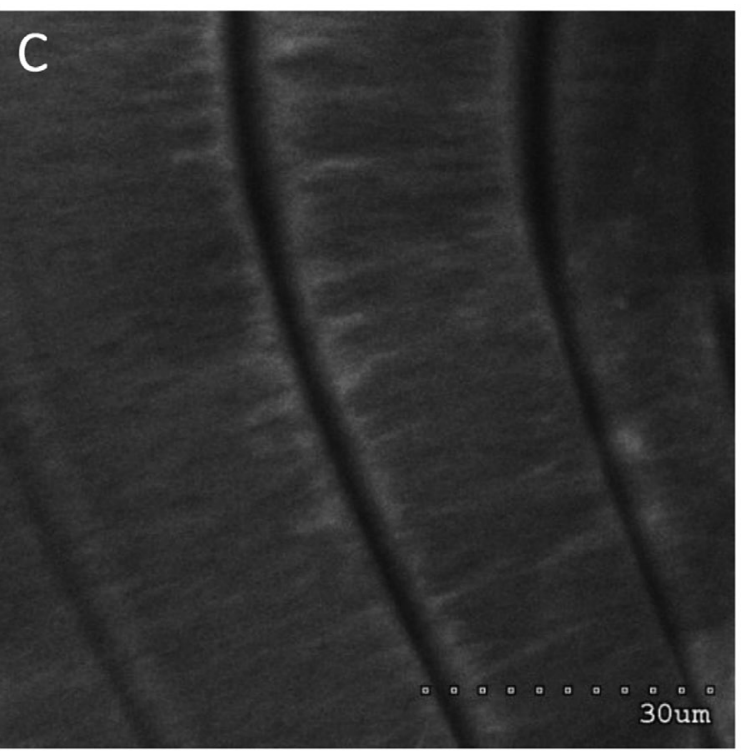

30 um
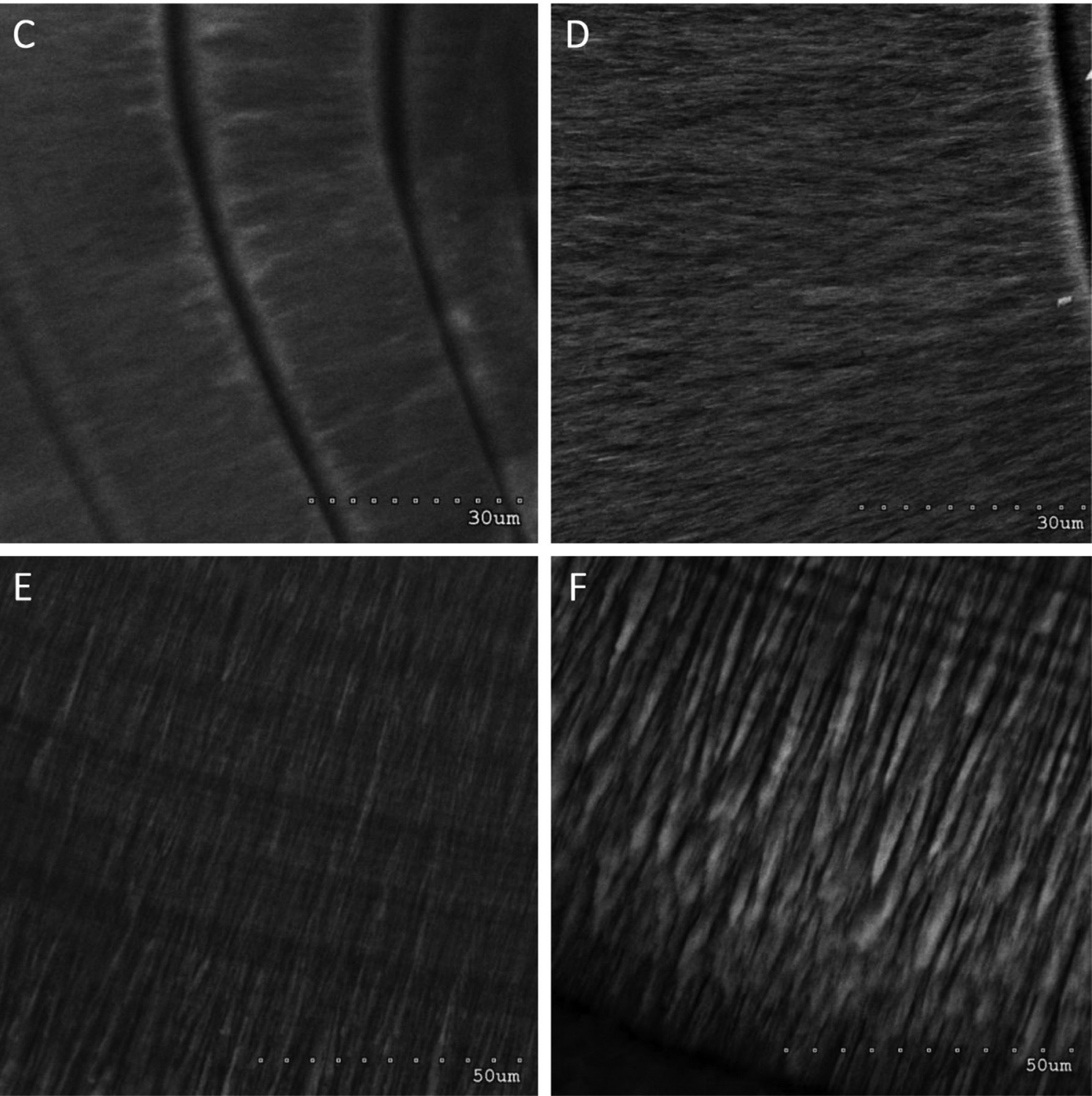

Fig. 3. - Scanning electron microphotography (SEM) of selected otoliths of Ceratoscopelus maderensis from the western Mediterranean Sea. (A) Larval zone: the transition between the larval and metamorphic zones is observed. (B) Detail of the central core in (A). (C), (D) Details of the metamorphic zone. (E) Increments in the juvenile-adult zone. (F) The margin of the otolith. 


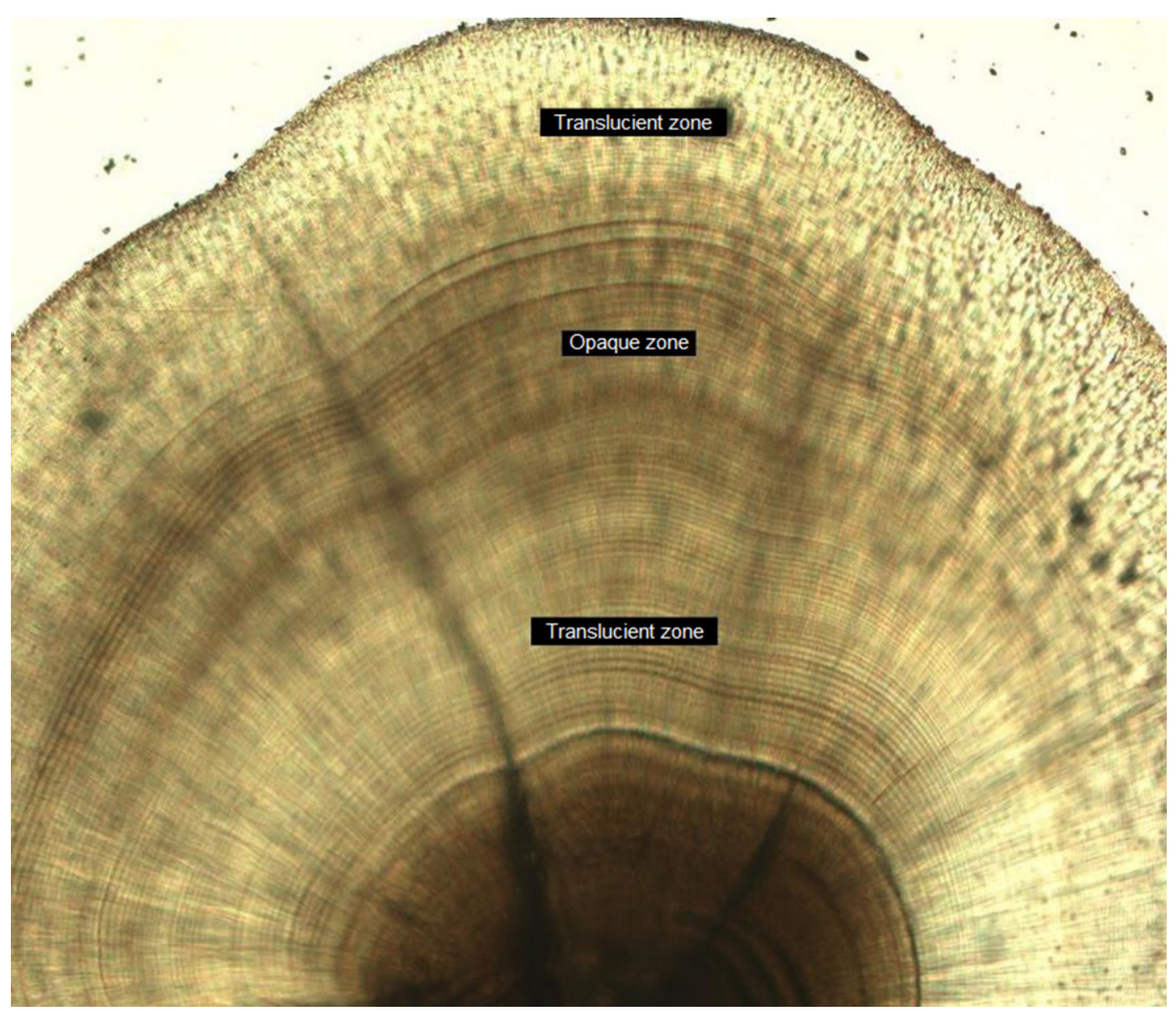

Fig. 4. - Detail $(100 \times)$ of the sagittae section of the postrostrum where two translucent and one opaque zone are distinguished in Ceratoscopelus maderensis from the western Mediterranean Sea.

Table 2. - Calculation of the standard length (SL) from successive translucent bands in the otoliths of Ceratoscopelus maderensis from the western Mediterranean Sea (our study) and the Atlantic Ocean (Linkowski et al. 1993). The first translucent band (I) corresponds to the one closest to the centre of the otolith. The number of increments was estimated using the resulting von Bertalanffy model. SD, standard deviation.

\begin{tabular}{lccccccc}
\hline \multirow{2}{*}{ Origin } & & \multicolumn{9}{c}{ SL (mm) } & & Source \\
\cline { 3 - 6 } & Translucent zones & Mean & SD & Range & N & Increments & This study \\
Western Mediterranean Sea & I & 22.11 & 3.50 & $18-29$ & 14 & 70 & This study \\
Western Mediterranean Sea & II & 39.87 & 4.05 & $33-46$ & 14 & 165 & This study \\
Western Mediterranean Sea & III & 50.30 & 6.31 & $42-64$ & 8 & 247 & Linkowski et al. 1993 \\
Atlantic Ocean & I & 25.14 & 6.88 & $15.8-39.5$ & 41 & 84 & Linkowski et al. 1993 \\
Atlantic Ocean & II & 35.27 & 6.25 & $23.9-46.1$ & 27 & 130 & Linkowski et al. 1993 \\
Atlantic Ocean & III & 41.82 & 6.86 & $34.4-59.5$ & 11 & 169 &
\end{tabular}

beginning of the juvenile-adult region (Fig. 3E, F). Increments in this region showed no clear pattern and were sometimes even unnoticeable or incomplete and irregular. This greatly hindered counting of the number of increments in this area, so estimates for this region should be taken with caution. Additionally, it made it difficult to obtain accurate measures of the mean increment thickness in this region, which was $142.46 \mu \mathrm{m}$ $(\mathrm{n}=14, \sigma=42.23)$. Finally, the juvenile-adult zone (Fig. $3 \mathrm{E}, \mathrm{F})$ consisted of well-defined increments that showed the typical radial structure and rhythmic growth patterns, as in other species. The mean increment thickness was $4.94 \mu \mathrm{m}(\mathrm{n}=22)$ and showed a decreasing trend towards the otolith edge (to $<1 \mu \mathrm{m}$ ) (Fig. $3 \mathrm{~F}$ ). In addition to the three development regions mentioned above, from one to three translucent regions were also observed along the radial axis of the otolith of adult individuals (Fig. 4). The radius of each of these translucent regions relating to both the fish SL and the number of increments in the otolith is shown in Table 2. 


\section{Growth}

The age interpretation of the otoliths under the optical microscope with coincident readings was successful in 59 individuals between $3.5 \mathrm{~mm}$ and $64 \mathrm{~mm} \mathrm{SL}$ (Table 1). Assuming that the frequency of increment formation in the otoliths of $C$. maderensis is daily, these individuals would be between 7 and 332 days old. The relationship between the number of increments and the SL, considering the full-size range of individuals, renders an asymptotic size of $70.59 \mathrm{~mm}$ and growth rates of 0.33 (for the smallest larvae) to 0.03 (for the largest adult specimen), with a growth rate decline through the development of $0.01 \mathrm{~mm}$ (Fig. 5, Tables 3 and 4).

Table S1 shows the estimates of the parameters of the von Bertalanffy growth curves that we obtained when considering adult specimens only (SL $>19 \mathrm{~mm})$, in order to assess growth differences between our specimens and those measured by Linkowski et al. (1993) (Fig. 6) in the northeastern Atlantic Ocean. The comparison of these two curves revealed that the best explanatory model (Model 1, Table 5) was the one in which the three parameters of the growth curve $\left(L_{\text {inf }} k\right.$ and $\left.t_{0}\right)$ had been fixed. This indicates that growth differences between our specimens and those measured by Linkowski et al. (1993) in the northeastern Atlantic Ocean are not statistically significant. Models 1, 2, 3 and 4 (Table 5) can be considered equivalent as their $\triangle \mathrm{AIC}$ values were $<2$. For body size, von Bertalanffy models predicted a SL of $72.82 \mathrm{~mm}$ for the Mediterranean individuals and 77.94 $\mathrm{mm}$ for the Atlantic ones (Table S1). However, considering the standard error obtained, body size differences between the Mediterranean and Atlantic specimens should be considered with caution.

\section{DISCUSSION}

This study provides for the first time the growth patterns of the lanternfish $C$. maderensis in the western Mediterranean Sea. Series of translucent bands alternating with more opaque ones were observed throughout the radius of the otolith across the ontogenetic development in agreement with observations by Linkowski et al. (1993) in Atlantic specimens. However, the age determination of $C$. maderensis had some uncertainties given the lack of clear increments during the metamorphic phase and the unknown period between hatching and the time at which the first increment is laid down. The complete reading of the number of increments in otoliths was particularly difficult in larger specimens ( $>40 \mathrm{~mm}$ SL) because the increments could not be read simultaneously across the entire otolith. In fact, only $28 \%$ of examined specimens could be successfully processed given these difficulties. While Linkowsky et al. (1993) applied the Ratke and Dean's (1982) regression model to predict the number of otolith increments in adults, in this study the preparation of the otoliths was optimized to enable the direct counting of increments from images obtained through the optical microscope. This allowed us to build a growth model using a single type of methodology to obtain all the data.

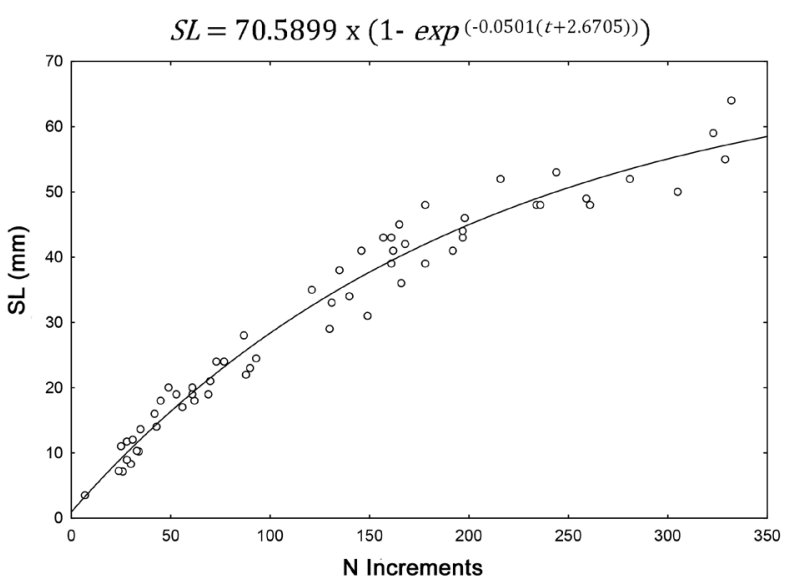

Fig. 5. - Relationship between the number of increments $(\mathrm{N})$ and standard length (SL) of Ceratoscopelus maderensis from the western Mediterranean Sea. Data were fitted to a von Bertalanffy growth model (see Methods section). t corresponds to the time in days.

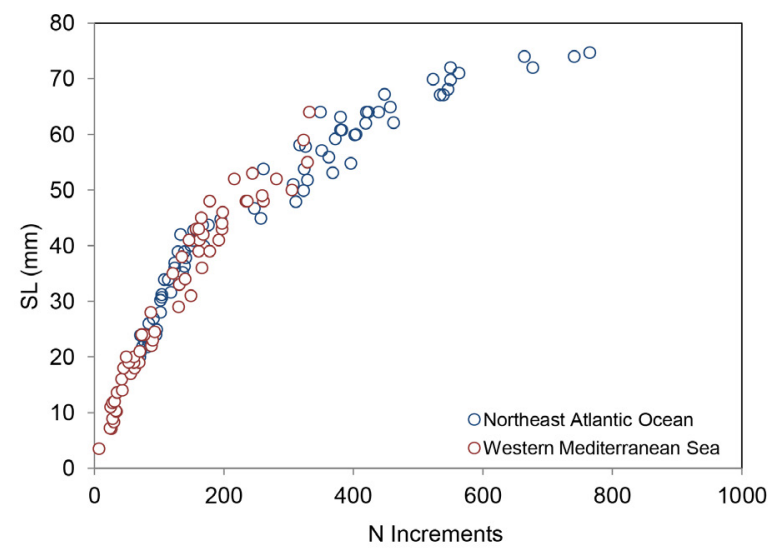

Fig. 6. - Comparison of the number of increments $(\mathrm{N})$ and standard length (SL) of Ceratoscopelus maderensis from the western Mediterranean Sea (red circles, this study) and the North Atlantic Ocean (green circles, Linkowski et al. 1993).

Table 3. - Parameters of the von Bertalanffy growth equation for Ceratoscopelus maderensis using the full-size range from larvae to adults from the western Mediterranean Sea.

\begin{tabular}{ccccc}
\hline \multicolumn{5}{c}{ CI $(95 \%)$} \\
\hline Parameter & Estimated & Lower limit & Upper limit & P \\
\hline$L_{\infty}(\mathrm{mm})$ & 70.59 & 61.1 & 80.08 & 0.0000 \\
$k\left(\right.$ days $\left.^{-1}\right)$ & 0.01 & 0 & 0.01 & 0.0000 \\
$t_{0}$ (days) & -2.67 & -10.61 & 5.27 & 0.5032 \\
\hline
\end{tabular}

C. maderensis larvae inhabit the surface layer up to $100 \mathrm{~m}$ depth during the day and at night (Olivar et al. 2014), but their feeding activity takes place only during daylight (Contreras et al. 2015). Thus, the photoperiod and the feeding activity of these early stages must play an important role in the deposition of calcium in the otoliths and the pattern of their increments (see Eckmann 2000, Morales-Nin 2000), which is in line with the reg- 
Table 4. - Growth rates (gt) as a function of size for the von Bertalanffy growth model in individuals from the western Mediterranean Sea and the Atlantic Ocean. SL, standard length.

\begin{tabular}{ccc}
\hline & $\begin{array}{c}\text { Western Mediterranean } \\
\text { Sea (this study) }\end{array}$ & $\begin{array}{c}\text { Atlantic Ocean } \\
\text { (Linkowski et al. 1993) }\end{array}$ \\
\hline SL $(\mathrm{mm})$ & $\mathrm{g}_{\mathrm{t}}$ & $\mathrm{g}_{\mathrm{t}}$ \\
\hline 5 & 0.33 & \\
10 & 0.30 & \\
15 & 0.28 & 0.21 \\
20 & 0.25 & 0.19 \\
25 & 0.23 & 0.17 \\
30 & 0.20 & 0.16 \\
35 & 0.18 & 0.14 \\
40 & 0.15 & 0.20 \\
45 & 0.13 & 0.10 \\
50 & 0.10 & 0.08 \\
55 & 0.08 & 0.07 \\
60 & 0.05 & 0.05 \\
65 & 0.03 & 0.03 \\
70 & & 0.01 \\
75 & & -0.01 \\
80 & & \\
\hline
\end{tabular}

ular deposition pattern that we observed in the larvae of our study. During the transformation phase, otoliths did not show such a definite deposition pattern, a finding that could probably be related to migration or feeding. This suggests that transformation individuals occur near the surface and at depths greater than $500 \mathrm{~m}$, with non-defined daily feeding patterns (Contreras et al. 2015, Olivar et al. 2018). The absence of behavioural patterns during this developmental stage appears to be reflected in the otolith growth, in which the regular deposition pattern was drastically lost, as occurs in other myctophid species (e.g. Ozawa and Peñaflor 1990, Gartner et al. 1991b, Takagi et al. 2006). As in other species, the end of this phase in $C$. maderensis is determined by the recovery of regularity in the deposition of the increments (e.g. Linkowski et al. 1993).

The wide depth range associated with the habitat of $C$. maderensis encompasses major changes in seawater temperature, pressure, light and food availability. For instance, when the adult fishes migrate to near-surface layers $(40-80 \mathrm{~m})$ at night, they are exposed to temperatures $\sim 18^{\circ} \mathrm{C}$. In contrast, during the daytime, adults remain in mesopelagic layers (200$1000 \mathrm{~m}$ ) where the water temperature is practically homogeneous at $\mathrm{ca} .13^{\circ} \mathrm{C}$. Considering this marked contrast in water temperature, it makes sense to assume that the specimens experience a period of adaptation during transformation, in which they do not perform the customary vertical migrations observed in adults. Therefore, during the transformation, $C$. maderensis might be experiencing gradual contact

Table 5. - Upper part: models considered to assess growth differences between our specimens of Ceratoscopelus maderensis from the western Mediterranean Sea (considering adult specimens only; SL $>19 \mathrm{~mm}$ ) and those measured by Linkowski et al. (1993) in the northeastern Atlantic Ocean, deviance, Akaike information criterion (AIC) values and Akaike weights (Wi). Lower part: estimates and standard error of the parameters of the four equivalent models $(\triangle \mathrm{AIC}<2$; Models $1,2,3$ and 4$)$. $\mathrm{L}_{\infty}$, asymptotic size $(\mathrm{mm})$; $k$, Brody growth coefficient $\left(\right.$ days $\left.{ }^{-1}\right)$; $\mathrm{t}_{0}$, age at which $L$ is 0 (days).

\begin{tabular}{|c|c|c|c|c|c|}
\hline Model & Fixed parameters & Deviance & AIC & $\Delta \mathrm{AIC}$ & Wi \\
\hline 1 & $\mathrm{~L}_{\text {inf }}, \mathrm{K}, \mathrm{t}_{0}$ & 1177.060 & 601.828 & 0.000 & 0.335 \\
\hline 2 & $\mathrm{~K}, \mathrm{t}_{0}$ & 1174.704 & 603.597 & 1.770 & 0.138 \\
\hline 3 & $\mathrm{~L}_{\mathrm{inf}}, \mathrm{t}_{0}$ & 1175.638 & 605.458 & 1.861 & 0.132 \\
\hline 4 & $\mathrm{~L}_{\text {inf }}, \mathrm{K}$ & 1176.968 & 607.449 & 1.991 & 0.124 \\
\hline 5 & $\mathrm{~L}_{\mathrm{inf}}$ & 1162.267 & 609.995 & 2.545 & 0.094 \\
\hline 6 & $\mathrm{~K}$ & 1165.683 & 612.878 & 2.883 & 0.079 \\
\hline 7 & $\mathrm{t}_{0}$ & 1172.123 & 616.394 & 3.517 & 0.058 \\
\hline 8 & & 1159.323 & 620.648 & 4.254 & 0.040 \\
\hline \multicolumn{2}{|c|}{ Estimates for parameters $\pm \mathrm{SE}$} & Model 1 & Model 2 & Model 3 & Model 4 \\
\hline \multicolumn{2}{|c|}{$\mathrm{L}_{\text {inf } 1}$} & $76.16 \pm 1.983$ & $76.54 \pm 2.157$ & $76.43 \pm 2.124$ & $76.13 \pm 2.003$ \\
\hline \multicolumn{2}{|c|}{$\mathrm{L}_{\text {inf } 2}$} & & $77.16 \pm 2.872$ & & \\
\hline \multicolumn{2}{|c|}{$\mathrm{K}_{1}$} & $0.004 \pm 0.000$ & $0.004 \pm 0.000$ & $0.004 \pm 0.000$ & $0.004 \pm 0.000$ \\
\hline \multicolumn{2}{|c|}{$\mathrm{K}_{2}$} & & & $0.004 \pm 0.000$ & \\
\hline \multicolumn{2}{|c|}{$\mathrm{t}_{01}$} & $19.85 \pm 7.152$ & $-20.83 \pm 7.432$ & $-20.36 \pm 7.295$ & $-19.93 \pm 7.282$ \\
\hline \multicolumn{2}{|c|}{$t_{02}$} & & & & $-19.2 \pm 7.870$ \\
\hline
\end{tabular}


with the physicochemical conditions that the species will have to face when reaching the adult phase. Ultimately, adults exhibit diel vertical migrations to feed near the surface (Bernal et al. 2015) and remain without feeding activity in the mesopelagic zone during the light hours, as mentioned above (Hulley 1984, Olivar et al. 2012). Incremental deposition in the juvenile-adult phase involved well-defined increments, with a decreasing pattern in the increment thickness towards the otolith edge (to $<1 \mu \mathrm{m}$ ). This decreasing pattern could also be reversed in some cases, as described in other myctophids (e.g. Greely et al. 1999, Tomás and Panfili 2000). Therefore, the increment thickness in otoliths during the juvenile-adult phase might vary among individuals, probably as a result of short-term variations in food availability.

The temperature range in the sea surface and the mesopelagic waters is higher in the Mediterranean Sea than in the northeastern Atlantic Ocean (Salat et al. 2002, Olivar et al. 2012). This is particularly interesting below the thermocline in the Mediterranean Sea, where the temperature does not drop below $13^{\circ} \mathrm{C}$. In general, higher water temperature regimes speed up metabolic processes increasing growth in organisms. Furthermore, these temperature differences can be observed in the otolith microstructure (Degens et al. 1969). This may help to explain why growth rates declined more slowly from a certain body size in individuals from the western Mediterranean Sea. However, growth differences between individuals from the western Mediterranean Sea and those from the northeastern Atlantic Ocean were not statistically significant.

Many aspects of the biology and ecology of myctophids are still poorly understood and require further investigation for managing ecosystems, particularly under uncertain climate changes. This study provides further knowledge of the biology of this abundant myctophid, taking into account not only its entire life cycle but also a different geographical scenario. However, a more complete time coverage over the year and the validation of the daily periodicity of the increments are still necessary to achieve a more profound knowledge of the age and growth of the species.

\section{ACKNOWLEDGEMENTS}

The authors are very grateful to the IDEADOS project (CTM2008-04489-C03-02) and for the technical support offered by José Manuel Fortuño (ICM) and Silvia Pérez-Mayol of the Sclerochronology Service at IMEDEA(UIB-CSIC). Thanks are also due to the Department of Renewable Marine Resources of the Institute of Marine Sciences (ICM-CSIC) for their facilities. We especially thank Victor M. Tuset for his valuable support and advice, which undoubtedly helped to improve this manuscript.

\section{REFERENCES}

Aguilar-Pereira A., Quijano-Puerto L. 2016. Relations between fish length to weight, and otolith length and weight, of the lionfish Pterois volitans in the Parque Nacional Arrecife Alacranes, southern Gulf of Mexico. Rev. Biol. Mar. Oceanogr. 51: 469-474.
https://doi.org/10.4067/S0718-19572016000200025

Anderson T.R., Martin A.P., Lampitt R.S., et al. 2019. Quantifying carbon fluxes from primary production to mesopelagic fish using a simple food web model. ICES J. Mar. Sci. 76: 690-701. https://doi.org/10.1093/icesjms/fsx234

Bernal A. Olivar M.P., Maynou F., et al. 2015. Diet and feeding strategies of mesopelagic fishes in the western Mediterranean. Progr. Oceanogr. 135: 1-17. https://doi.org/10.1016/j.pocean.2015.03.005

Brothers E.B., Mathews C. P., Lasker R. 1976. Daily growth increments in otoliths from larval and adult fishes. Fish. Bull. 74: $1-8$.

Burnham K.P., Anderson D.R. 2002. Model Selection and Multimodel Inference: A Practical Information-Theoretic Approach. 2nd ed. Springer-Verlag, New York.

Burnham K.P., Anderson D.R. 2004. Multimodel inference: Understanding AIC and BIC in model selection. Sociol. Methods Res., 33: 261-304. https://doi.org/10.1177/0049124104268644

Cavallaro M., Battaglia P., Guerrera M.C., et al. 2019. Structure and ultrastructure study on photophores of the Madeira lanternfish, Ceratoscopelus maderensis (Lowe, 1839), Pisces: Myctophidae. Acta Zool. 100: 89-95. https://doi.org/10.1111/azo.12236

Contreras T., Olivar M.P., Bernal A., et al. 2015. Comparative feeding patterns of early stages of mesopelagic fishes with vertical habitat partitioning. Mar. Biol. 162: 2265-2277. https://doi.org/10.1007/s00227-015-2749-y

Degens E.T., Deuser W.G., Haedrich, R.L.1969. Molecular structure and composition of fish otoliths. Mar. Biol. 2: 105-113. https://doi.org/10.1007/BF00347005

Eckmann R. 2000. The influence of photoperiod and feeding frequency on the distinctness of daily otolith increments in larval whitefish (Coregonus lavaretus L.). Limnologica 30: 102-105. https://doi.org/10.1016/S0075-9511(00)80003-1

Emery W.J., Meincke J. 1986. Global water masses: summary and review. Oceanol. Acta, 9: 383-391.

Estrada M. 1985. Primary production at the deep chlorophyll maximum in the western Mediterranean. In: Gibbs P.E. (ed): Proc. Nineteenth Eur. Mar. Biol. Symp., pp. 135-143. https://doi.org/10.1007/978-1-4899-2248-9 12

Gartner J.V.Jr. 1991a. Life histories of three species of lanternfishes (Pisces: Myctophidae) from the eastern Gulf of Mexico. Mar. Biol. 111: 11-20. https://doi.org/10.1007/BF01986340

Gartner J.V.Jr. 1991b. Life histories of three species of lanternfishes (Pisces: Myctophidae) from the eastern Gulf of Mexico (II). Age and growth patterns. Mar. Biol. 111: 21-27. https://doi.org/10.1007/BF01986340

Goodyear R.H., Gibbs R.H.Jr., Roper C.F.E., et al. 1972. Mediterranean biological studies. Smithson. Institution Washington DC Rep. 1-278.

Greely T.M., Gartner J.V.Jr., J.J. Torres. 1999. Age and growth of Electrona Antarctica (Pisces: Myctophidae), the dominant mesopelagic fish of the Southern Ocean. Mar. Biol. 133: 145-158. https://doi.org/10.1007/s002270050453

Gjøsaeter H. 1987. Primary growth increments in otoliths of six tropical myctophid species. Biol. Oceanogr. 4: 359-382.

Gjøsaeter J., Kawaguchi K.A. 1980. A review of the world resources of mesopelagic fish. FAO Fisheries Technical Paper 193: $1-151$.

Handeland S.O., Imsland A.K., Stefansson S.O. 2008. The effect of temperature and fish size on growth, feed intake, food conversion efficiency and stomach evacuation rate of Atlantic salmon post-smolts. Aquaculture. 283: 36-42. https://doi.org/10.1016/j.aquaculture.2008.06.042

Harvey J.T., Loughlin T.R., Perez M.A., et al. 2000. Relationship between fish size and otolith length for 63 species of fishes from the eastern North Pacific Ocean. NOAA/National Marine Fisheries Service, Seattle. NOAA Tech. Rep. NMFS 150: 1-36.

Hayashi A., Kawaguchi K., Watanabe H., et al. 2001. Daily growth increment formation and its lunar periodicity in otoliths of the myctophid fish Myctophum asperum (Pisces: Myctophidae). Fish. Sci. 67: 811-817. https://doi.org/10.1046/j.1444-2906.2001.00327.x

Houpert L., Testor P., Durrieu de Madron X., et al. 2015. Seasonal cycle of the mixed layer, the seasonal thermocline and the upper-ocean heat storage rate in the Mediterranean Sea derived from observations. Prog. Oceanogr. 132: 333-352. 
https://doi.org/10.1016/j.pocean.2014.11.004

Hulley P.A. 1981. Results of the research cruises of FRV "Walther Herwig" to South America. LVIII. Family Myctophidae. Archiv. Fischwiss. 31: 1-300.

Hulley P.A. 1984. Myctophidae. In: Whitehead P.J.P., Bauchot M.L., et al. (eds), Fishes of the North-eastern Atlantic and the Mediterranean. UNESCO. 1: 429-483.

Jonsson G. 1992. Islenskir fiskar. Fiolvi. Reykjavik, Iceland. pp. 568.

Kendall A. W., Ahlstrom E.H., Moser H.G. 1984. Early life history stages of fishes and their characters. In: Moser H.G., Richards W.J., Cohen D.M et al. (eds), Ontogeny and Systematics of Fishes, Am. Soc. Ichthyol. Herpetol. 1: $11-22$.

Linkowsky T.B., Radtke R.L., Lenz, P.H., 1993. Otolith microstructure, age and growth of two species of Ceratoscopelus (Osteichthyes: Myctophidae) from the eastern North Atlantic. Jour. Exp. Mar. Biol. Ecol. 167: 237-260. https://doi.org/10.1016/0022-0981(93)90033-K

Methot R.D. Jr, Kramer D. 1981. Growth of northern anchovy, Engraulis mordax, and northern lampfish, Stenobrachius leucopsarus. Rapp. P-v. Rèun. Cons. Int. l'Explor. Mer 178: 424-431.

Moku M., Hayashi A., Mori K., et al. 2005. Validation of daily otolith increment formation in the larval myctophid fish $\mathrm{Di}$ aphus slender-type spp. J. Fish Biol. 67: 1481-1485. https://doi.org/10.1111/j.0022-1112.2005.00824.X

Morales-Nin B.1992. Determination of growth in bony fishes from otolith microstructure. FAO Fisheries Technical Paper. No. 322. Rome, FAO. $51 \mathrm{pp}$ http://www.fao.org/3/t0529e/T0529E00.htm

Morales-Nin B. 2000. Review of the growth regulation processes of otolith daily increment formation. Fish. Res. 46: 53-67. https://doi.org/10.1016/S0165-7836(00)00133-8

Morel A., André J.M. 1991. Pigment Distribution and Primary Production in the western Mediterranean as derived and modelled from coastal zone color scanner observations. J. Geophys. Res., 96 C7: 12685-12698. https://doi org/10.1029/91JC00788.

Moser H.G., Watson W. 2006. Myctophidae. In: Richards W.J. (eds), Early Stages of Atlantic Fishes: An identification guide for the western central North Atlantic. Taylor and Francis Group, U.S., pp. 473-589.

Mytilineou C., Politou C.Y., Papaconstantinou C., et al. 2005. Deep-water fish fauna in the Eastern Ionian Sea. Belg. J. Zool. 135: 229-233.

Naciri M., Lemaire C., Borsa P. et al. 1999. Genetic study of the Atlantic/Mediterranean transition in sea bass (Dicentrarchus labrax), J.Hered. 90: 591-596. https://doi.org/10.1093/jhered/90.6.591

Ogle D.H. 2016. Introductory fisheries Analyses with R. Chapman \& Hall/CRC, Boca Raton. https://doi.org/10.1201/b19232

Olivar M.P., Bernal A., Molí B. et al. 2012. Vertical distribution, diversity and assemblages of mesopelagic fishes in the western Mediterranean. Deep-Sea Res. I 62: 53-69. https://doi.org/10.1016/i.dsr.2011.12.014

Olivar M.P., Sabatés A., Alemany F., et al. 2014. Diel-depth distributions of fish larvae off the Balearic Islands (western Mediterranean) under two environmental scenarios. J. Mar. Syst. 138: 127-138. https://doi.org/10.1016/j.jmarsys.2013.10.009

Olivar M.P. Contreras T., Hulley P.A., et al. 2018. Variation in the diel vertical distributions of larvae and transforming stages of oceanic fishes across the tropical and equatorial Atlantic. Progr. Oceanogr. 160: 83-100. https://doi.org/10.1016/i pocean.2017.12.005

Ozawa T., Peñaflor C. 1990. Otolith Microstructure and early ontogeny of a myctophid species, Benthosema pterotum. Nippon Suisan Gakk. 56: 1987-1995. https://doi.org/10.2331/suisan.56.1987

Ratke R.L., Dean J.M. 1982. Increment formation in the otoliths of embryos, larvae, and juveniles of the mummichog, Fundulus heteroclitus. Fish. Bull. 80: 201-215.

Richards W.J. 2005. Early stages of Atlantic fishes: An identification guide for the western central North Atlantic. Taylor \& Francis, Boca Raton, FL. 1: 524-525. https://doi.org/10.1201/9780203500217

Ricker W.E. 1975. Computation and interpretation of biological statistics of fish populations. Bull. Fish. Res. Board Can. 191: 207-211.
Rountrey A.N., Coulson P.G., Meeuwig J.J., et al. 2014. Water temperature and fish growth: otoliths predict growth patterns of a marine fish in a changing climate. Glob. Change Biol. 20: $2450-2458$

https://doi.org/10.1111/gcb.12617

Salat J., García M.A., Cruzado A., et al. 2002. Seasonal changes of water mass structure and shelf slope exchanges at the Ebro shelf (NW Mediterranean). Cont. Shelf Res.22: 327-346. https://doi.org/10.1016/S0278-4343(01)00031-0

Sarmiento-Lezcano A., Triay-Portella R., Castro J.J., et al. 2018. Age-based life-history parameters of the mesopelagic fish Notoscopelus resplendens (Richardson, 1845) in the Central Eastern Atlantic. Fish. Res. 204: 412-423. https://doi.org/10.1016/j.fishres.2018.03.016

Sassa C., Takahashi M. 2018. Comparative larval growth and mortality of mesopelagic fishes and their predatory impact on zooplankton in the Kuroshio region. Deep-Sea Res. I 131: 121-132. https://doi.org/10.1016/j.dsr.2017.11.007

Sassa C. Kawaguchi K. Hirota Y, et al. 2007. Distribution depth of the transforming stage larvae of myctophid fishes in the subtropical-tropical waters of the western North Pacific. Deep-Sea Res. I 54: 2181-2193. https://doi.org/10.1016/j.dsr.2007.09.006

Sassa C., Takahashi M., Tsukamoto Y. 2015. Distribution, hatch-date, growth, and mortality of larval Benthosema pterotum (Pisces: Myctophidae) in the shelf region of the East China Sea. J. Mar. Biol. Assoc. U.K. 95: 161-174. https://doi.org/10.1017/S0025315414001209

Saunders R.A., Lourenço S., Vieira R.P., et al. 2020. Age and growth of Brauer's lanternfish Gymnoscopelus braueri and rhombic lanternfish Krefftichthys anderssoni (Family Myctophidae) in the Scotia Sea, Southern Ocean. J. Fish. Biol.96:364-377. https://doi.org/10.1111/jfb.14206

Secor D.H., Dean J.M., Laban E.H. 1991. Manual for otolith removal and preparation for microstructure examination. Baruch Inst. Mar. Biol. Coast. Res. 85 pp.

Silva A., Carrera P., Massé J., et al. 2008. Geographical variability of sardine growth across the northeastern Atlantic and the Mediterranean Sea. Fish. Res. 90: 56-69. https://doi.org/10.1016/j.fishres.2007.09.011

Stevenson D.K., Campana S.E. 1992. Otolith Microstructure examination and Analysis. Can. B. Fish. Aquat. Sci. 117: $1-126$. https://doi.org/10.1007/BF00043932

St. John M.A., Borja A., Chust G., et al. 2016. A dark hole in our understanding of marine ecosystems and their services: perspectives from the mesopelagic community. Front. Mar. Sci. 3: 31. https://doi.org/10.3389/fmars.2016.00031

Tåning A.V. 1918. Mediterranean Scopelidae: (Saurus, Aulopus, Chlorophthalmus, and Myctophum). Rep. Danish oceanogr. Exped. 1908-1910, 2(A7): 1-154.

Takagi K., Yatsu A., Moku M., et al. 2006. Age and growth of lanternfishes, Symbolophorus californiensis and Ceratoscopelus warmingii (Myctophidae), in the Kuroshio-Oyashio Transition Zone. Ichthyol. Res.53: 281-289. https://doi.org/10.1007/s10228-006-0346-2

Tomás J., Panfili J. 2000. Otolith microstructure examination and growth patterns of Vinciguerria nimbaria (Photichthydae) in the tropical Atlantic Ocean. Fish. Res. 46:131-145. https://doi.org/10.1016/S0165-7836(00)00140-5

Tuset V.M., Lombarte A., Assis C.A. 2008. Otolith atlas for the western Mediterranean, north and Central Eastern Atlantic. Sci. Mar. 72S1: 7-198. https://doi.org/10.1007/s10228-006-0346-2

Von Bertalanffy L. 1938. A quantitative theory of organic growth. Hum. Biol. 10: 181-213.

Wang Y., Zhang J., Chen Z., et al. 2018. Age and growth of Myctophum asperum in the South China Sea based on otolith microstructure analysis. Deep-Sea Res. II 167: 121-127. https://doi.org/10.1016/j.dsr2.2018.07.004

Young J.W., Bulman C.M., Blaber S.J.M., et al. 1988. Age and growth of the lanternfish Lampanyctodes hectoris (Myctophidae) from eastern Tasmania, Australia. Mar. Biol. 99: 569-576. https://doi.org/10.1007/BF00392564 
Scientia Marina 85(2)

June 2021, S1-S2, Barcelona (Spain)

ISSN-L: 0214-8358

\section{Growth patterns of the lanternfish Ceratoscopelus maderensis in the western Mediterranean Sea}

Enric Real, Ainhoa Bernal, Beatriz Morales-Nin, Balbina Molí, Itziar Alvarez, M. Pilar Olivar Supplementary material 
Fig. S1. - Frequency distribution of the standard length (SL) of individuals considered in this study $(\mathrm{N}=59)$.

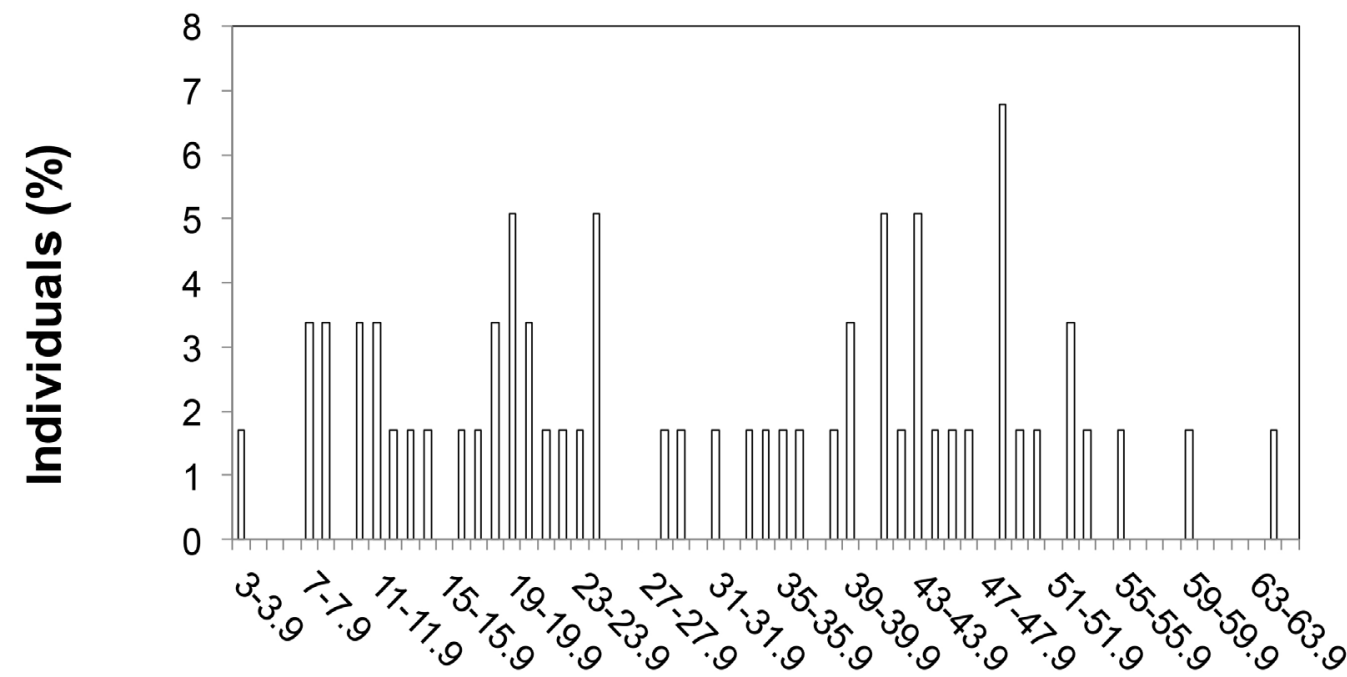

\section{SL range $(\mathrm{mm})$}

Table S1. - Estimates and standard error of the parameters of the von Bertalanffy curves obtained when comparing the growth of our adult specimens (SL>19mm) with those measured by Linkowski et al. (1993) in the northeast Atlantic Ocean. Lळ: asymptotic size (mm); k: Brody's growth coefficient $\left(\right.$ days $\left.^{-1}\right) ; \mathrm{t}_{0}$ : age at which $\mathrm{L}$ is 0 (days).

\begin{tabular}{ccccccc}
\hline & \multicolumn{3}{c}{$\begin{array}{c}\text { Western Mediterranean Sea } \\
\text { (this study) }\end{array}$} & \multicolumn{3}{c}{$\begin{array}{c}\text { Northeast Atlantic Ocean } \\
\text { (Linkowski et al. 1993) }\end{array}$} \\
\hline Parameter & Estimate & Standard error & $\mathrm{P}$ & Estimate & standard error & $\mathrm{P}$ \\
$\mathrm{L}_{\infty}(\mathrm{mm})$ & 72.82 & 8.272 & $<0.001$ & 77.94 & 2.611 & $<0.001$ \\
$\mathrm{k}($ days & & $1.19 \mathrm{e}^{-3}$ & $<0.001$ & $3.63 \mathrm{e}^{-3}$ & $3.85 \mathrm{e}^{-4}$ & $<0.001$ \\
$\mathrm{t}_{0}$ (days) & $4.59 \mathrm{e}^{-3}$ & 13.50 & $>0.05$ & -28.59 & 10.10 & $<0.01$ \\
\hline
\end{tabular}

